Article

\title{
Catalytic wet oxidation of aniline over Ru catalysts supported on a modified $\mathrm{TiO}_{2}$
}

\author{
Mingguang Song, Yunsong Wang \#, Yun Guo *, Li Wang, Wangcheng Zhan, Yanglong Guo, \\ Guanzhong Lu \\ Key Laboratory for Advanced Materials and Research Institute of Industrial Catalysis, School of Chemistry and Molecular Engineering, East China \\ University of Science and Technology, Shanghai 200237, China
}

\section{A R T I C L E I N F O}

\section{Article history:}

Received 15 March 2017

Accepted 2 May 2017

Published 5 July 2017

\section{Keywords:}

Catalystic wet air oxidation

Physico-chemical

Aniline removal

Carbon deposites

\begin{abstract}
A B S T R A C T
The catalytic wet air oxidation of aniline over $\mathrm{Ru}$ catalysts supported on modified $\mathrm{TiO}_{2}\left(\mathrm{TiO}_{2}\right.$, $\mathrm{Ti}_{0.9} \mathrm{Ce}_{0.1} \mathrm{O}_{2}, \mathrm{Ti}_{0.9} \mathrm{Zr}_{0.1} \mathrm{O}_{2}$ ) is investigated. A series of characterization techniques are conducted to determine the relationship between the physico-chemical properties and the catalytic performance. As a result of the good metal dispersion and large number of surface oxygen species, the $\mathrm{Ru} / \mathrm{Ti}_{0.9} \mathrm{Zr}_{0.1} \mathrm{O}_{2}$ catalyst presents the best catalytic activity among the tested samples. The effects of the operating conditions on the reaction are investigated and the optimal reaction conditions are determined. Based on the relationship between the by-products concentration and the reaction time, the reaction path for the catalytic oxidation of aniline is established. Carbonaceous deposits on the surface of the support are known to be the main reason for catalyst deactivation. The catalysts maintain a constant activity even after three consecutive cycles.
\end{abstract}

(C) 2017, Dalian Institute of Chemical Physics, Chinese Academy of Sciences. Published by Elsevier B.V. All rights reserved.

\section{Introduction}

Nitrogenous pollutants are one of the most harmful contaminants in natural water, and large quantities of these substances are discharged directly into the environment, leading to serious pollution [1,2]. Aniline, a model nitrogen-containing compound originating from different sources (e.g., dyes, polymers, pesticides, fertilizers and paintings) [3], is easily adsorbed through the skin, which can cause headaches, nausea, vomiting and other symptoms. According to the sewage treatment standard of the US Environmental Protection Agency, the emission standards for aniline is limited to $262 \mu \mathrm{g} / \mathrm{L}$ in water [4]. Therefore, an effective water treatment method is impera- tive to detoxify aniline.

At present, the conventional treatment methods for organic sewage include physical adsorption, biological degradation and advanced oxidation processes [5-7]. The physical adsorption method simply transfers the pollutants onto a porous solid surface. However, the organic compounds cannot be degraded into non-toxic substances and still pose a threat to the environment. Although bio-degradation is widely used in organic sewage treatment, the highly toxic matter (e.g., aniline) always inactivates biological bacteria. As an advanced oxidation technology, catalytic wet air oxidation (CWAO) is promising to convert toxic, non-biodegradable and highly concentrated organic compounds to $\mathrm{CO}_{2}, \mathrm{H}_{2} \mathrm{O}$ and other innocuous

\footnotetext{
* Corresponding author. Fax: +86-021-64252943; E-mail: yunguo@ecust.edu.cn

\# Corresponding author. Fax: +86-021-64253703; E-mail: yswang@ecust.edu.cn

This work was financially supported by the National Natural Science Foundation of China (21333003, 21577034), National Basic Research Program of China (2013CB933200), National High Technology Research and Development Program of China (2015AA034603), and the Fundamental Research Funds for the Central Universities (WJ1514020).

DOI: 10.1016/S1872-2067(17)62848-1 | http://www.sciencedirect.com/science/journal/18722067 | Chin. J. Catal., Vol. 38, No. 7, July 2017
} 
end-products using oxygen or air as the oxidizing agent [8].

In practical sewage treatment, an ideal catalyst becomes the key factor of the CWAO technology for industrial application. Therefore, great efforts have been made to research highly efficient catalysts. Various types of homogeneous and heterogeneous catalysts for the oxidation of model compounds (e.g., phenol, carboxylic acids, N-containing compounds) have been developed $[9,10]$. Homogeneous catalysts (e.g., $\mathrm{Cu}^{2+}, \mathrm{Fe}^{3+}, \mathrm{Mn}^{2+}$ ) have some merits such as better diffusion and a more active center in solution, which are favorable for the catalytic performance [11]. However, an additional separate step is essential to prevent secondary pollution. Hence, the heterogeneous catalysts have attracted more and more attention over the years owing to their high activity and easy separation $[12,13]$. Noble metal catalysts (such as $\mathrm{Pt}, \mathrm{Ru}, \mathrm{Pd}, \mathrm{Ir}$ ) supported on carbon materials or oxides (such as $\mathrm{CeO}_{2}, \mathrm{ZrO}_{2}, \mathrm{TiO}_{2}$ ) have been widely investigated in the CWAO of organic compounds [14,15]. Sergio et al. [16] considered that the conversion of aniline was enhanced by increasing the catalyst porosity and Pt dispersion. Barbier et al. [17] revealed that the addition of Pd into the $\mathrm{Ru} / \mathrm{CeO}_{2}$ catalyst improved the aniline conversion and the nitrogen selectivity. Castillejos-López et al. [18] compared the support effects in Ru catalysts applied for CWAO of aromatic compounds, and concluded that the use of activated carbon as a support enhanced the conversion and mineralization.

Although $\mathrm{Ru}$ is the most effective metal for CWAO of nitrogenous organics, the phenomenon of catalytic deactivation has inhibited its wide application. For example, Ru leaching has been verified since a complexation reaction occurs between the nitrogen atom and noble metal [19]. In addition, the formation of carbonaceous deposits on the catalyst surface decreases the collision probability between the active components and the organic matter [20]. Therefore, it is of great interest to develop a catalyst with the properties of high catalytic activity and excellent stability.

In this article, $\mathrm{TiO}_{2}$ is modified by doping zirconium or cerium into the crystal lattice. To determine the optimum reaction conditions for the degradation of aniline, the influence of the reaction temperature and reaction pressure are investigated. In addition, the concentration of the reaction by-products with time on-stream is evaluated over $\mathrm{Ru} / \mathrm{Ti}_{0.9} \mathrm{Zr}_{0.1} \mathrm{O}_{2}$ so as to establish the reaction path. To explore the relationship between the catalytic physico-chemical properties and the reaction activity, the corresponding characterization techniques, such as X-ray diffraction (XRD), $\mathrm{N}_{2}$ adsorption, high resolution transmission electron microscopy (HR-TEM), X-ray photoelectron spectroscopy (XPS), and hydrogen temperature-programmed reduction ( $\mathrm{H}_{2}$-TPR), are conducted.

\section{Experimental}

\subsection{Catalyst preparation}

According to the previously reported procedure [21], all of the investigated supports were prepared by the sol-gel method. Typically, a tetrabutyl orthotitanate $\left(\mathrm{Ti}\left(\mathrm{OC}_{4} \mathrm{H}_{9}\right)_{4}\right)$ solution, as titanic precursor, was quickly added into ethanol (95\%) under continuous agitation until a white colloidal substance was generated owing to the reactant mixture hydrolysis reaction. Then, the obtained pseudo-gels were dried in an oven at $120^{\circ} \mathrm{C}$ for 12 h. Finally, all samples were calcined at $500{ }^{\circ} \mathrm{C}$ for $6 \mathrm{~h}$ at a heating rate of $2{ }^{\circ} \mathrm{C} / \mathrm{min}$. The preparation of $\mathrm{Ti}_{0.9} \mathrm{Zr}_{0.1} \mathrm{O}_{2}$ and Tio. $\mathrm{Ce}_{0.1} \mathrm{O}_{2}$ supports followed the same operation steps, where the alcohol solution, containing $\mathrm{ZrOCl}_{2} \cdot 8 \mathrm{H}_{2} \mathrm{O}$ and $\mathrm{Ce}$ $\left(\mathrm{NO}_{3}\right)_{3} \cdot 6 \mathrm{H}_{2} \mathrm{O}$, was gradually transferred to the $\mathrm{Ti}\left(\mathrm{OC}_{4} \mathrm{H}_{9}\right)_{4}$ precursor solution. After a period of time for stirring, the yielded pseudo-gels were further treated as the $\mathrm{TiO}_{2}$ processing steps.

Catalysts containing $2 \mathrm{wt} \% \mathrm{Ru}$ were prepared by the excessive impregnation method using aqueous solutions of ruthenium chloride. First, the prepared mixed oxides were immersed in the precursor solution of Ru salts under stirring for $6 \mathrm{~h}$, then the excess water was removed by rotary evaporation. The obtained powders were separately reduced at $300{ }^{\circ} \mathrm{C}$ for $3 \mathrm{~h}$ under flowing $\mathrm{H}_{2}(60 \mathrm{~L} / \mathrm{h})$ to achieve the as-prepared catalysts.

\subsection{Catalyst test}

The catalytic wet oxidation reactions were performed in a $250 \mathrm{~mL}$ batch reactor which was equipped with a magnetically driven stirrer and an electric heating jacket. In a typical run, 0.3 $\mathrm{g}$ of the catalyst and $75 \mathrm{~mL}$ of the aniline model compound, with an initial chemical oxygen demand (COD) concentration of $5300 \mathrm{mg} / \mathrm{L}$, were added into the reaction kettle. To avoid diffusion limitations, a high stirring speed $(900 \mathrm{r} / \mathrm{min})$ was selected. Before heating, the reaction kettle was repeatedly purged with nitrogen to replace the air. When the temperature was increased to the desired point, oxygen was introduced into the reactor. This was taken as the "zero" time for the reaction. Then, samples were periodically acquired from the reactor. The non-catalyst oxidation reaction was also carried out under identical operating conditions. After the reaction, the used catalysts were recovered from the solution for the purpose of the cyclic experiment.

\subsection{Analysis methods}

The evolution of the concentration of aniline and organic intermediates was analyzed by high-performance liquid chromatography (Agilent 1200) equipped with an Agilent ODS-C18 column and a UV-detector set at $254 \mathrm{~nm}$. The isocratic elution was a mixture of methanol:water $=60: 40$ (vol/vol) with a flow rate of $0.45 \mathrm{~mL} / \mathrm{min}$.

The concentrations of ammonia, nitrite, and nitrate ions in the liquid samples were monitored using an ion chromatograph (HPIC, Dionex) equipped with a cationic column (CS12A, $4 \mathrm{~mm} \times 250 \mathrm{~mm}$ ) and an anionic column (AS14A, $4 \mathrm{~mm} \times 250$ $\mathrm{mm})$. The mobile phases for the cations and anions were $\mathrm{HNO}_{3}$ (1.7 mmol/L)/dipicolinic acid (0.7 mmol/L) and $\mathrm{Na}_{2} \mathrm{CO}_{3}(3.2$ $\mathrm{mmol} / \mathrm{L}) / \mathrm{NaHCO}_{3}(1 \mathrm{mmol} / \mathrm{L})$, respectively.

The COD and total nitrogen content (TN) were determined by a 6B-2000 multiple parameter water quality analyzer. Prior to measurement, the samples were digested using the special reagent at 150 and $120{ }^{\circ} \mathrm{C}$, respectively. The TN was determined using the alkaline $\mathrm{K}_{2} \mathrm{~S}_{2} \mathrm{O}_{8}$ ultraviolet method. In this arti- 
cle, the TN represented the total amount of ammonium ions, nitrate ions, nitrite ions and all the nitrogenous organic matter in solution. The nitrogen balance was established by comparing the TN values and the calculated chromatography (both HPLC and HPIC) results. The maximum deviation was less than $\pm 5 \%$ in both cases. The total organic carbon (TOC) was measured with a liquiTOC analyzer.

\subsection{Characterization}

Nitrogen adsorption-desorption was performed at $-196{ }^{\circ} \mathrm{C}$ using a NOVA $4200 \mathrm{e}$ apparatus to determine the special surface area by the Brunauer-Emmett-Teller (BET) model. Before the adsorption, the samples were degassed overnight at $150{ }^{\circ} \mathrm{C}$.

The crystalline structure of the catalysts was explored on a Rigaku D/MAX 2550 VB/PC X-ray diffractometer with $\mathrm{Cu} K_{\alpha}$. The operating voltage and current were at $40 \mathrm{kV}$ and $40 \mathrm{~mA}$, respectively. XRD patterns were recorded in the $2 \theta=10^{\circ}-80^{\circ}$ range with a scanning speed of $6^{\circ} / \mathrm{min}$. The average crystal size of the catalysts was calculated according to the Debye-Scherrer equation:

$$
D=0.90 \lambda / \beta \cos \theta
$$

where $D$ is the crystal size (nm), $\lambda$ is the wavelength (nm), $\beta$ is the peak width at half maximum (rad) and $\theta$ is the Bragg angle (rad).

The solution after reaction was analyzed by ICP-OES to check the leaching of the constituents of the catalyst (i.e., $\mathrm{Ru}, \mathrm{Ti}$, Zr and Ce) upon the CWAO.

The catalyst morphology was determined by HRTEM on a JEM-2100 equipped with a $\mathrm{LaB}_{6}$ filament and a Gatan Ultrascan CCD camera with a resolution of $2 \mathrm{k} \times 2 \mathrm{k}$. The catalysts were dispersed in ethanol solution by ultrasonication, and a drop of the suspension was deposited on a copper screen coated with carbon film (mesh 300).

The XPS spectra were recorded on a Thermo ESCALAB 250 spectrometer with a monochromatized $\mathrm{Al} K_{\alpha} \mathrm{X}$-ray source $(1486.6 \mathrm{eV}$ ) and a pass energy of $25 \mathrm{eV}$. The $\mathrm{C} 1 \mathrm{~s}$ (binding energy $284.6 \mathrm{eV}$ ) of adventitious carbon was used as the reference.

$\mathrm{H}_{2}$-TPR experiments were performed on a Pengxiang PX200 adsorption instrument. About $80 \mathrm{mg}$ of the sample was placed in a U-shaped quartz tube, and then reduced under $5 \% \mathrm{H}_{2}$ gas flow (50 mL/min) from 50 to $800{ }^{\circ} \mathrm{C}$ at $10{ }^{\circ} \mathrm{C} / \mathrm{min}$. The consumption of hydrogen was monitored by a thermal conductivity detector (TCD).

\section{Results and discussion}

\subsection{Characterization}

The BET surface areas of the catalysts are shown in Table 1. The BET surface areas of modified $\mathrm{TiO}_{2}$ by $\mathrm{Ce}$ and/or $\mathrm{Zr}$ were larger than that of the original $\mathrm{TiO}_{2}$. These results demonstrated that the dopant in the $\mathrm{TiO}_{2}$ network had a positive effect on the surface area, which might facilitate the metal dispersion and/or provide more space for Ru loading [22]. After impregnation of a precious metal, the specific surface area of the cata-
Table 1

Ru loading, special surface area, crystal particle size, and average particle size of the supported Ru catalysts.

\begin{tabular}{lcccc}
\hline Catalyst & $\begin{array}{c}\text { Ru loading a } \\
\text { (wt\%) }\end{array}$ & $\begin{array}{c}\text { BET } \\
\left(\mathrm{m}^{2} / \mathrm{g}\right)\end{array}$ & $\begin{array}{c}\text { Crystal } \\
\text { particle size } \\
(\mathrm{nm})\end{array}$ & $\begin{array}{c}\text { Average size } \\
\text { of particle }^{\mathrm{c}} \\
(\mathrm{nm})\end{array}$ \\
\hline $\mathrm{TiO}_{2}$ & - & 64.1 & 21.0 & - \\
$\mathrm{Ti}_{0.9} \mathrm{Ce}_{0.1} \mathrm{O}_{2}$ & - & 91.2 & 13.6 & - \\
$\mathrm{Ti}_{0.9} \mathrm{Zr}_{0.1} \mathrm{O}_{2}$ & - & 109.3 & 11.7 & - \\
$\mathrm{Ru} / \mathrm{TiO}_{2}$ & 1.5 & 46.4 & 25.3 & 6.2 \\
$\mathrm{Ru} / \mathrm{Ti}_{0.9} \mathrm{Ce}_{0.1} \mathrm{O}_{2}$ & 1.7 & 89.7 & 13.8 & 5.7 \\
$\mathrm{Ru} / \mathrm{Ti}_{0.9} \mathrm{Zr}_{0.1} \mathrm{O}_{2}$ & 1.8 & 94.1 & 12.4 & 3.8 \\
\hline
\end{tabular}

a Detected by ICP.

bCalculated by Scherrer's equation.

c Obtained by TEM.

lysts decreased, especially for $\mathrm{Ru} / \mathrm{TiO}_{2}$. The real $\mathrm{Ru}$ loading on three supports ranged from 1.5 to $1.8 \mathrm{wt} \%$, which was close to the calculated loading of $2 \mathrm{wt} \%$.

\subsection{1. $X R D$}

Fig. 1 shows the XRD diffraction patterns of the catalysts. In all cases, the intensive diffraction peaks appearing around $25.3^{\circ}, 37.0^{\circ}, 38.6^{\circ}, 48.0^{\circ}, 54.0^{\circ}, 55.1^{\circ}, 62.1^{\circ}$ and $68.7^{\circ}$ were assigned to anatase phases (PDF21-1272). For the Ru catalysts supported on $\mathrm{TiO}_{2}$, small peaks at $27.5^{\circ}$ and $36^{\circ}$ were detected, owing to the large particle size of $\mathrm{RuO}_{2}$, which could be ascribed to the (110) and (101) planes of tetragonal $\mathrm{RuO}_{2}$ (JCPDS 21-1172) [23]. After the incorporation of zirconium and cerium ions into the cubic lattice of $\mathrm{TiO}_{2}$, no additional peaks were observed, indicating the formation of a solid solution to maintain the exclusive anatase crystal texture. Additionally, no diffraction peaks attributed to $\mathrm{Ru}$ species were observed in the $\mathrm{Ru} / \mathrm{Ti}_{0.9} \mathrm{Ce}_{0.1} \mathrm{O}_{2}$ and $\mathrm{Ru} / \mathrm{Ti}_{0.9} \mathrm{Zr}_{0.1} \mathrm{O}_{2}$ samples. This might arise from the low $\mathrm{Ru}$ content or the high dispersion of the metal species on the support surface. The other reason could be the presence of $\mathrm{Ru}$ in the form of the amorphous phase. Compared with the carrier $\mathrm{TiO}_{2}$, the intensity of the diffraction peak appeared to decline over the Ru catalyst. This observation indicated the strong interaction between the active sites and the support maintained the integrity of the crystal shape. Table 1 also presents the crystal size of different catalysts as calculated

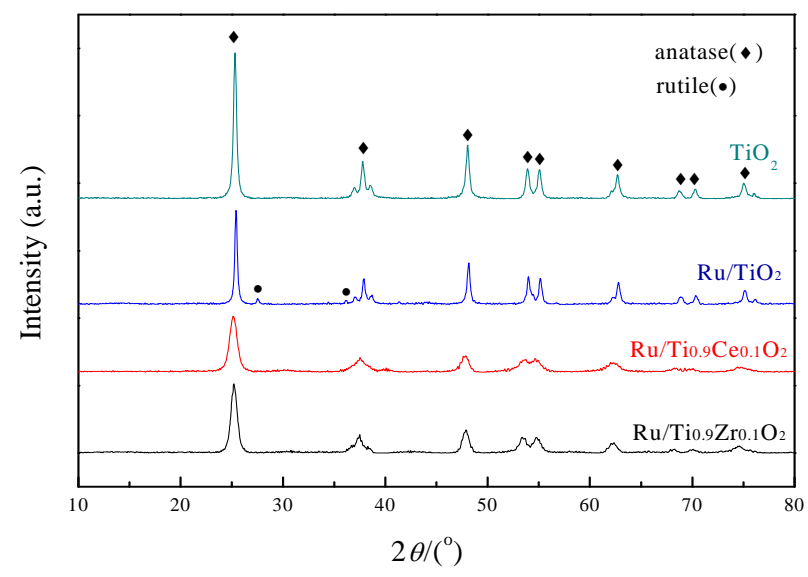

Fig. 1. XRD patterns of the $\mathrm{TiO}_{2}$ and the supported Ru catalysts. 

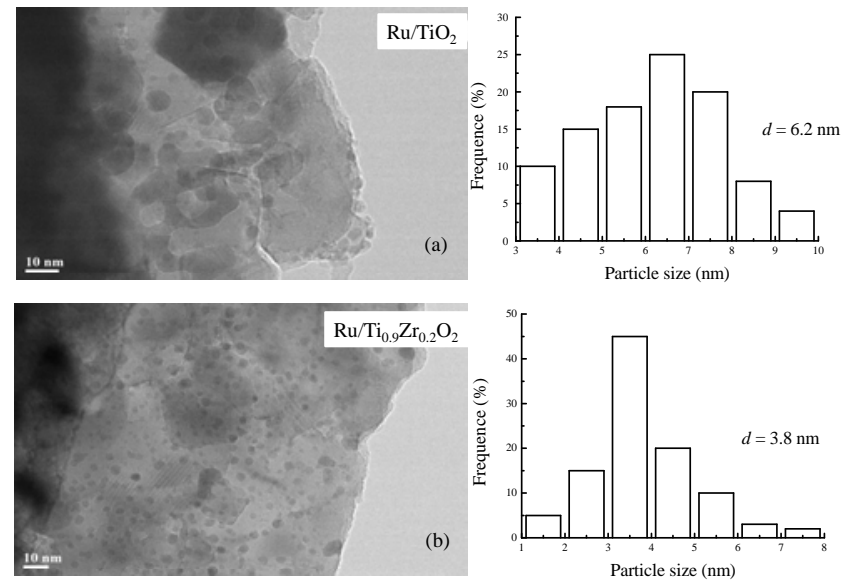

Fig. 2. HRTEM images and the particle size distribution of (a) $2 \mathrm{wt} \%$ $\mathrm{Ru} / \mathrm{TiO}_{2}$ and (b) $2 \mathrm{wt} \% \mathrm{Ru} / \mathrm{Ti}_{0.9} \mathrm{Zr}_{0.1} \mathrm{O}_{2}$.

by Scherrer's equation. The catalysts containing $\mathrm{Zr}$ or Ce with $10 \mathrm{wt} \%$ possessed a smaller crystal particle size (approximately $13 \mathrm{~nm}$ ) compared with $\mathrm{Ru} / \mathrm{TiO}_{2}$ (approximately $25 \mathrm{~nm}$ ). The above results further confirmed that the modified $\mathrm{TiO}_{2}$ had a positive effect on reducing the crystal size of Ru-supported catalysts.

\subsubsection{HRTEM}

Fig. 2 shows HRTEM images of the Ru-based catalysts. The surface micrographs showed that the approximate sizes of metal particles ranged from 1 to $10 \mathrm{~nm}$. The $\mathrm{Zr}$ dopant could effectively reduce the sizes of noble metal particles and enable a high metal dispersion on the support surface. In the image of $\mathrm{Ru} / \mathrm{TiO}_{2}$, metal coalescence occurred with a large particle size of approximately $6.2 \mathrm{~nm}$. In accordance with the above results, the $\mathrm{Ti}_{0.9} \mathrm{Zr}_{0.1} \mathrm{O}_{2}$ support was ideal for maintaining better $\mathrm{Ru}$ dispersion and smaller particle size.

\subsubsection{XPS}

Fig. 3 shows the $01 s$ XPS spectra of the catalysts, which could be deconvoluted into three peaks. The significant spectral

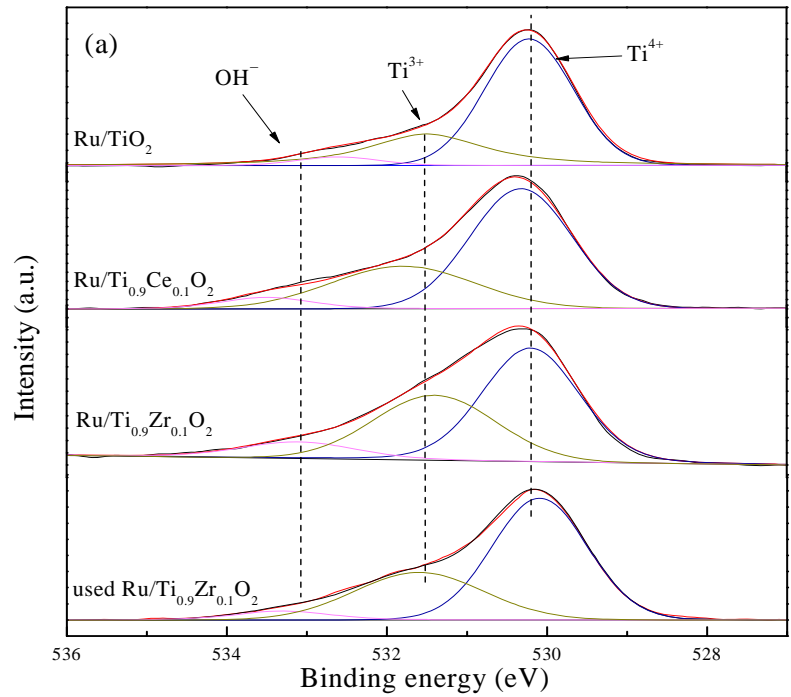

region, at the low binding energy of 530.1-530.3 eV, was assigned to $\mathrm{Ti}-\mathrm{O}$ in $\mathrm{TiO}_{2}$. The second oxygen species, at approximately 531.4-531.6 eV, was attributed to $\mathrm{Ti}-\mathrm{O}$ in $\mathrm{Ti}_{2} \mathrm{O}_{3}$, which was a so-called surface active oxygen species. The above two types of oxygen species originated from the lattice oxygen, while the last signal of $01 s$, with a binding energy of 532.3-532.8 eV, was attributed to the surface hydroxyl group $[24,25]$. The relative abundance of the oxygen species was included in the analysis (Table 2). The $\mathrm{Ru} / \mathrm{Ti}_{0.9} \mathrm{Zr}_{0.1} \mathrm{O}_{2}$ catalyst possessed the highest relative abundance of surface active oxygen species (36.7\%), which was the main reason for the best catalytic activity.

Fig. 3 shows the XPS spectra of Ru $3 d_{3 / 2}$ and Ru $3 d_{5 / 2}$ for the fresh and spent catalysts. The peak for $\mathrm{C} 1 s$ was centered at $284.6 \mathrm{eV}$, which was attributed to the standard carbon species. The other peaks for C-OR were observed at $286 \mathrm{eV}$ and 288.5 $\mathrm{eV}$ as a result of carbonaceous pollution in the exposure of the environment and the incomplete calcination of the supports [26]. Additionally, they exhibited distinct Ru species peaks. The low binding energy of approximately $280.0-281.5 \mathrm{eV}$ was ascribed to $3 d_{5 / 2}$ with a respective $3 d_{3 / 2}$ core level binding energy of approximately $285.5-287.0 \mathrm{eV}$, which corresponded to the reduced $\mathrm{Ru}^{0}$. The other peak, at approximately $282.0-283.5 \mathrm{eV}$, was assigned to $3 d_{5 / 2}$ with a respective $3 d_{3 / 2}$ core level binding energy of approximately 285.5-287.4 eV, which corresponded to oxidized $\mathrm{Ru}^{4+}[27,28]$. The curve-fitting results for the XPS spectra in the $\mathrm{Ru} 3 d$ region are summarized in Table 2 . The $\mathrm{Ru}^{4+}$ relative ratio in $\mathrm{Ru} / \mathrm{Ti}_{0.9} \mathrm{Zr}_{0.1} \mathrm{O}_{2}$, was increased to $59.2 \%$, which was larger than the $\mathrm{Ru} / \mathrm{TiO}_{2}$ catalyst with $25.4 \%$. This could be explained by the strong interaction between the doped zirconium and the $\mathrm{TiO}_{2}$ lattice causing a larger amount of surface reactive oxygen species, which oxidized the reduced species of ruthenium $\mathrm{Ru}^{0}$ into $\mathrm{Ru}^{4+}$.

\subsection{4. $H_{2}-T P R$}

The redox properties of $\mathrm{Ru} / \mathrm{TiO}_{2}, \mathrm{Ru} / \mathrm{Ti}_{0.9} \mathrm{Ce}_{0.1} \mathrm{O}_{2}$ and $\mathrm{Ru} / \mathrm{Ti}_{0.9} \mathrm{Zr}_{0.1} \mathrm{O}_{2}$ catalysts were investigated by TPR. As shown in Fig. 4, the low-temperature reduction peaks, in the range of

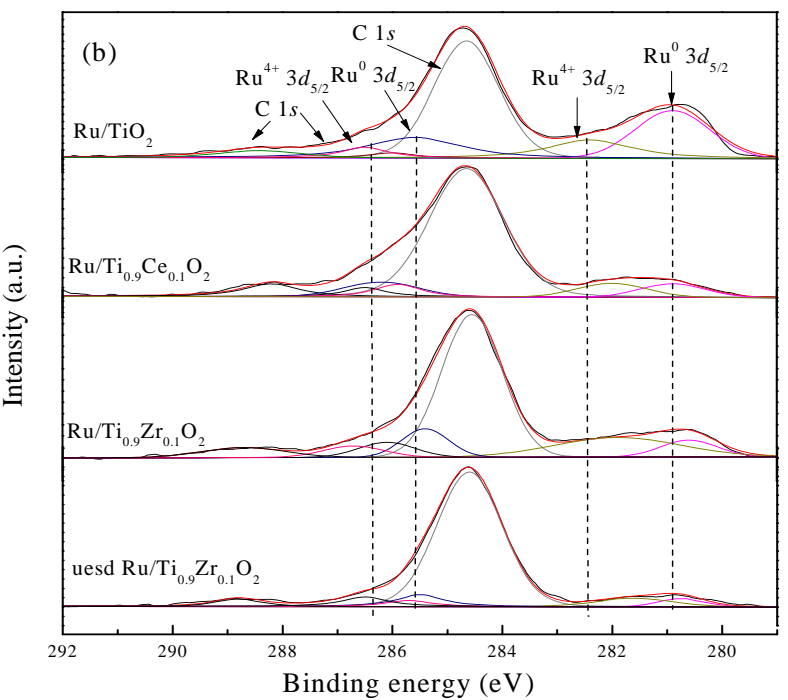

Fig. 3. $01 s$ (a) and Ru 3d (b) XPS spectra of the fresh and spent Ru-based catalysts. 
Table 2

XPS analysis of the fresh and used catalyst: relative abundance of the $01 s$ and Ru $3 d$ species.

\begin{tabular}{|c|c|c|c|c|c|}
\hline \multirow{2}{*}{ Catalyst } & \multicolumn{3}{|c|}{$01 s$ relative abundance $(\%)$} & \multicolumn{2}{|c|}{$\mathrm{Ru} 3 d$ relative abundance (\%) } \\
\hline & $01 s\left(\mathrm{TiO}_{2}\right)$ & $01 s\left(\mathrm{Ti}_{2} \mathrm{O}_{3}\right)$ & $01 s(\mathrm{OH})$ & $\mathrm{Ru}^{0}$ & $\mathrm{Ru}^{4+}$ \\
\hline $2 \% \mathrm{Ru} / \mathrm{TiO}_{2}$ & 72.5 & 22.7 & 4.8 & 74.6 & 25.4 \\
\hline $2 \% \mathrm{Ru} / \mathrm{Ti}_{0.9} \mathrm{Ce}_{0.1} \mathrm{O}_{2}$ & 62.6 & 31.5 & 5.9 & 56.5 & 43.5 \\
\hline $2 \% \mathrm{Ru} / \mathrm{Ti}_{0.9} \mathrm{Zr}_{0.1} \mathrm{O}_{2}$ & 53.8 & 36.7 & 9.5 & 40.8 & 59.2 \\
\hline (Used) $\mathrm{Ru} / \mathrm{Ti}_{0.9} \mathrm{Zr}_{0.1} \mathrm{O}_{2}$ & 62.1 & 32.6 & 5.3 & 42.9 & 57.1 \\
\hline
\end{tabular}

$70-140{ }^{\circ} \mathrm{C}$, were associated to the reduction of $\mathrm{RO}_{2}$ to metallic $\mathrm{Ru}[29,30]$. For the $\mathrm{Ru} / \mathrm{Ti}_{0.9} \mathrm{Ce}_{0.1} \mathrm{O}_{2}$ catalyst, a main reduction peak at $130{ }^{\circ} \mathrm{C}$ was attributed to the reduction of poorly crystal or so-called amorphous $\mathrm{RuO}_{x}$. Additionally, the shoulder peak at $105{ }^{\circ} \mathrm{C}$ was assigned to the reduction of highly dispersed amorphous $\mathrm{RuO}_{x}$ [31]. In this case, the reducibility of the $\mathrm{RuO}_{2}$ clusters was strongly affected by the particle size of the catalyst. According to the above explanation, we ascribed the reduction peaks at 100 and $130{ }^{\circ} \mathrm{C}$ to different types of Ru species. On $\mathrm{Ru} / \mathrm{Ti}_{0.9} \mathrm{Zr}_{0.1} \mathrm{O}_{2}$, the reduction peak exhibited a narrow structure and high intensity, which was in agreement with the high metal dispersion and uniform particle size distribution. The reduction peaks of the $\mathrm{Ru}$ supported on modified $\mathrm{TiO}_{2}$ at $300-400{ }^{\circ} \mathrm{C}$ were stronger than those of the $\mathrm{Ru} / \mathrm{TiO}_{2}$ catalyst, which was ascribed to the presence of a strong interaction between $\mathrm{RuO}_{x}$ and the support at the interface that remarkably enhanced the catalytic activity [32]. Notably, the presence of zirconium in $\mathrm{TiO}_{2}$ has been shown to reduce the $\mathrm{Ti}-\mathrm{O}$ bonding energy and accelerate the flow of lattice oxygen [33]. The $\mathrm{H}_{2}$ uptake during the reduction of $\mathrm{RuO}_{2}$ was calculated in Table 3, which was close to the theoretical values of $\mathrm{H}_{2}$ consumption on the basis of the reduction of $\mathrm{RuO}_{2}$ to $\mathrm{Ru}$. Among the catalysts, the $\mathrm{Ru} / \mathrm{Ti}_{0.9} \mathrm{Zr}_{0.1} \mathrm{O}_{2}$ exhibited the highest $\mathrm{H}_{2}$ consumption, which was consistent with the XPS and ICP results (higher proportion of $\mathrm{Ru}^{4+}$ species and more ruthenium species on the support).

\subsection{WAO of aniline}

First, the thermal stability of the aniline molecule was evaluated in the absence of catalyst under a nitrogen atmosphere instead of oxygen. The thermal degradation of aniline was nearly negligible after $5 \mathrm{~h}$ of reaction at $180^{\circ} \mathrm{C}$. After cooling to

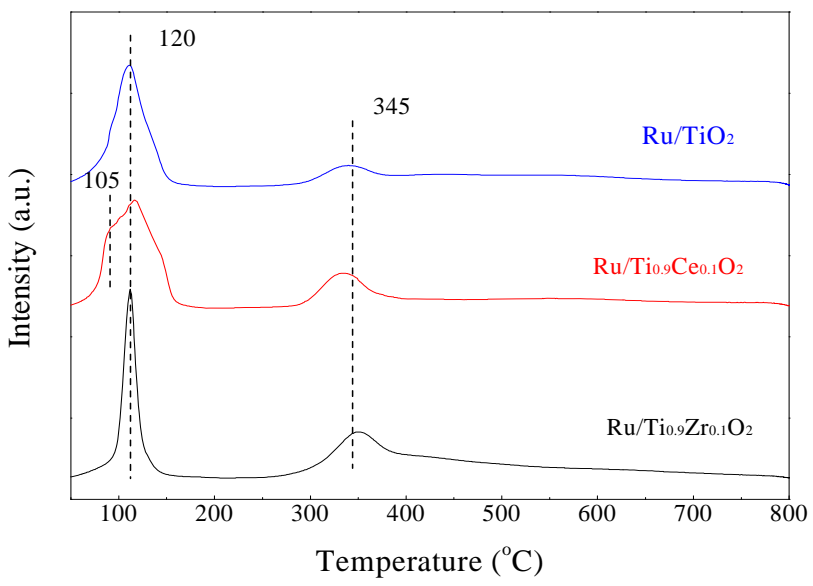

Fig. 4. $\mathrm{H}_{2}$-TPR profiles of various catalysts. room temperature, the concentration of aniline was kept constant. Therefore, most of the organic compounds were in solution rather than volatilizing into the gas phase.

Fig. 5 shows the evolution of the TOC and TN concentration upon WAO at $180{ }^{\circ} \mathrm{C}$ at a $1.5 \mathrm{MPa}$ oxygen pressure. The TOC removal was approximately $12.1 \%$ and an analogous horizontal line was observed for TN. From the chromatographic (LPLC-MS) analysis, some reaction intermediates (such as phenol, benzoquinone, hydroquinone, and nitrobenzene) were identified. Actually, some organic compounds were more difficult to degrade than aniline under such reaction conditions. Hence, harsher operating conditions were required to achieve a satisfactory conversion, even in the presence of noble metal catalysts [34-36]. The values of TOC and TN were directly obtained by using a multiple parameter controller, and were in good agreement with the calculated results. Consequently, most of the by-products could be accurately identified and quantified.

\subsection{Support effects in ruthenium catalysts for catalytic wet oxidation of aniline}

The catalytic wet oxidation of aniline over the supports and the supported $\mathrm{Ru}$ catalysts was further performed at $180{ }^{\circ} \mathrm{C}$ and $1.5 \mathrm{MPa}$ total oxygen pressure. Fig. 6 shows the concentration of aniline, COD, and TN as a function of time. In the presence of the supports, the conversion of aniline was higher than the WAO of aniline. The $\mathrm{Ti}_{0.9} \mathrm{Zr}_{0.1} \mathrm{O}_{2}$ support achieved $67.7 \%$ aniline conversion after $5 \mathrm{~h}$, which exhibited better catalytic performance compared with the $\mathrm{Ti}_{0 .}{ }_{9} \mathrm{Ce}_{0.1} \mathrm{O}_{2}$ and $\mathrm{TiO}_{2}$ supports. However, the COD and TN conversion was only $20 \%$ and $15 \%$ after $5 \mathrm{~h}$ of reaction, respectively. This could be explained by the formation of intermediate species in the CWAO of aniline. Hence, the supports were unable to convert the intermediate species into eco-friendly matter under the current reaction conditions.

As a general observation, the Ru-based catalysts exhibited higher activity than the supports. As shown in Table 4, the initial reaction rate increased from $1.56 \mathrm{mmol}$ ani $/\left(\mathrm{h} \cdot \mathrm{g}_{\mathrm{cat}}\right)$ for

Table 3

Hydrogen consumption from the $\mathrm{H}_{2}$-TPR measurements.

\begin{tabular}{lccc}
\hline Catalyst & $\begin{array}{c}\text { Total } \mathrm{H}_{2} \\
\text { consumption } \\
(\mu \mathrm{mol} / \mathrm{g})\end{array}$ & $\begin{array}{c}\mathrm{H}_{2} \text { consumption } \\
\text { at } 70-150{ }^{\circ} \mathrm{C} \\
(\mu \mathrm{mol} / \mathrm{g})\end{array}$ & $\begin{array}{c}\mathrm{H}_{2} \text { consumption } \\
\text { at 300-400 } \\
(\mu \mathrm{C} C\end{array}$ \\
\hline $\mathrm{Ru} / \mathrm{TiO}_{2}$ & 88.5 & 67.2 & 18.3 \\
$\mathrm{Ru} / \mathrm{Ti}_{0.9} \mathrm{Ce}_{0.1} \mathrm{O}_{2}$ & 154.9 & 108.9 & 46.0 \\
$\mathrm{Ru} / \mathrm{Ti}_{0.9} \mathrm{Zr}_{0.1} \mathrm{O}_{2}$ & 180.5 & 129.2 & 51.3 \\
\hline
\end{tabular}



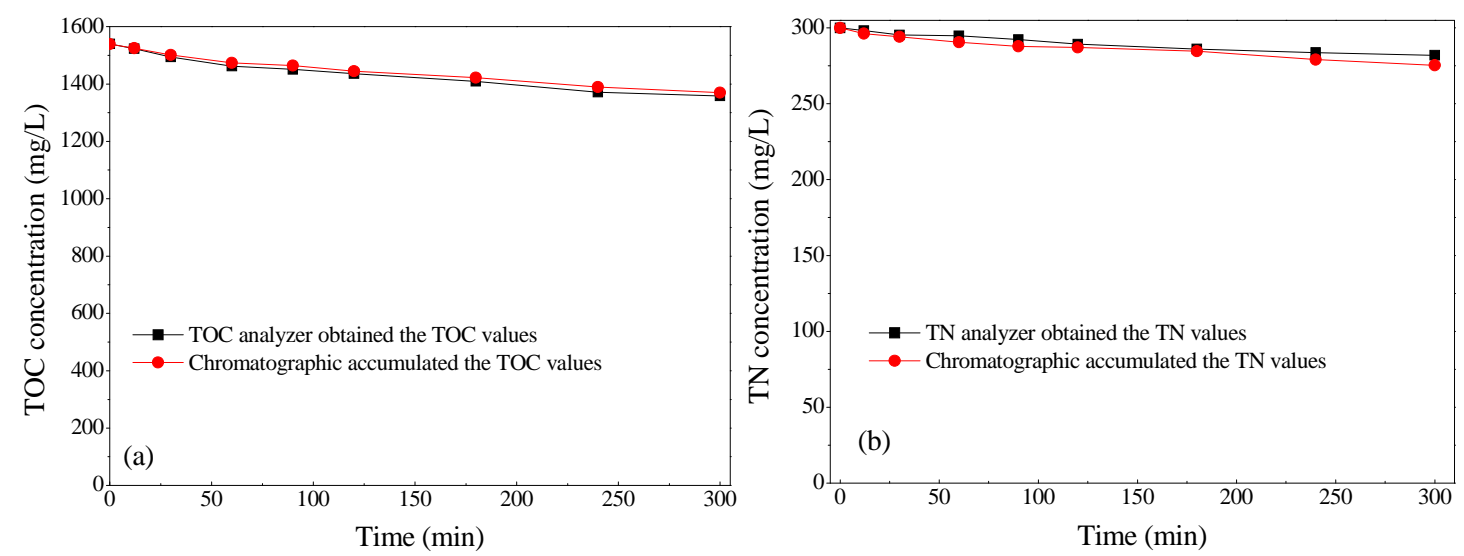

Fig. 5. Non-catalytic wet air oxidation of aniline. (a) TOC concentration; (b) TN concentration.
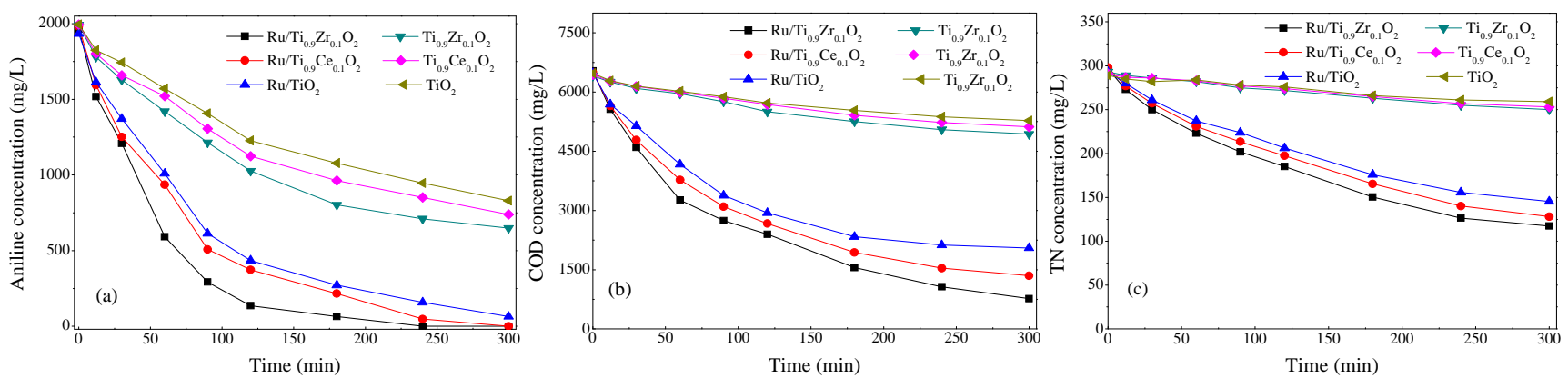

Fig. 6. CWAO of aniline over different catalysts. (a) Aniline concentration; (b) COD concentration; (c) TN concentration.

$\mathrm{Ti}_{0.9} \mathrm{Zr}_{0.1} \mathrm{O}_{2}$ to $3.78 \mathrm{mmol}$ ani $/\left(\mathrm{h} \cdot \mathrm{g}_{\text {cat }}\right.$ ) for $\mathrm{Ru} / \mathrm{Ti}_{0.9} \mathrm{Zr}_{0.1} \mathrm{O}_{2}$. Over the $\mathrm{Ru} / \mathrm{Ti}_{0.9} \mathrm{Zr}_{0.1} \mathrm{O}_{2}$ catalyst, the complete aniline conversion was achieved after a short time and the COD removal reached 88.3\% after $5 \mathrm{~h}$. As reported earlier, the Ru-based catalyst exhibited better catalytic behavior owing to its higher $\mathrm{C}-\mathrm{C}$ bond cleavage capacity [37]. The other Ru-based catalysts exhibited the same tendency.

Interestingly, the activity of the reaction was affected by the supports. Over the $\mathrm{Ru} / \mathrm{Ti}_{0.9} \mathrm{Zr}_{0.1} \mathrm{O}_{2}$ catalyst, the catalyst exhibited higher activities compared with those of the $\mathrm{Ru} / \mathrm{TiO}_{2}$ and $\mathrm{Ru} / \mathrm{Ti}_{0.9} \mathrm{Ce}_{0.1} \mathrm{O}_{2}$. The bare supports as catalysts presented the same tendency. These results indicated that the larger specific surface area and pore volume for the $\mathrm{Ti}_{0.9} \mathrm{Zr}_{0.1} \mathrm{O}_{2}$ support could provide the precious metal with more space. Meanwhile, the characteristics of the supports made the Ru metal form larger particles. Hence, the $\mathrm{Ti}_{0.9} \mathrm{Zr}_{0.1} \mathrm{O}_{2}$ catalyst had more active sites for the oxidation of organic matter. Since the doping of zirconium into $\mathrm{TiO}_{2}$ resulted in an increase of the redox of the $\mathrm{Ru} / \mathrm{Ti}_{0.9} \mathrm{Zr}_{0.1} \mathrm{O}_{2}$, this could explain the cause of the high degradation activities.

Table 4

$\mathrm{WAO}$ and CWAO of aniline over the supports and the supported catalysts.

\begin{tabular}{lccccccc}
\hline & $\mathrm{WAO}$ & $\mathrm{TiO}_{2}$ & $\mathrm{Ti}_{0.9} \mathrm{Ce}_{0.1} \mathrm{O}_{2}$ & $\mathrm{Ti}_{0.9} \mathrm{Zr}_{0.1} \mathrm{O}_{2}$ & $\mathrm{Ru} / \mathrm{TiO}_{2}$ & $\mathrm{Ru} / \mathrm{Ti}_{0.9} \mathrm{Ce}_{0.1} \mathrm{O}_{2}$ & $\mathrm{Ru} / \mathrm{Ti}_{0.9} \mathrm{Zr}_{0.1} \mathrm{O}_{2}$ \\
\hline Rini $^{\mathrm{a}}\left(\mathrm{mmol}_{\text {ani }} /\left(\mathrm{h} \cdot\right.\right.$ cat $\left._{\text {cat }}\right)$ & - & 1.15 & 1.29 & 1.56 & 2.66 & 2.86 & 3.78 \\
Conversion $^{\mathrm{b}}(\%)$ & 50.4 & 58.5 & 62.2 & 67.7 & 96.7 & 100 & 100 \\
$\Delta \mathrm{COD}^{\mathrm{b}}(\%)$ & 21.2 & 18.8 & 20.5 & 21.4 & 68.1 & 74.2 & 88.3 \\
$\Delta \mathrm{TN}^{\mathrm{b}}(\%)$ & 5.2 & 15.2 & 16.0 & 16.3 & 46.1 & 58.4 & 61.2 \\
\hline
\end{tabular}

a Average degradation rate of aniline in $1 \mathrm{~h}$.

b Degradation percentage of aniline in $5 \mathrm{~h}$.
The selectivity towards $\mathrm{N}_{2}$ was also an important factor for the CWAO process of nitrogen-containing species. Unfortunately, the TN abatement was low, even in the presence of a precious metal. Fig. 6(c) illustrates the $\mathrm{N}_{2}$ selectivity over Ru-based catalysts, which was consistent with the results reported by Oliviero et al. [38]. This showed that the inorganic nitrogen species, such as $\mathrm{NH}_{4}{ }^{+}$, and $\mathrm{NO}_{3}{ }^{-}$, was detrimental towards oxidation.

Indeed, the modified $\mathrm{TiO}_{2}$, by doping with $\mathrm{Zr}$ and $\mathrm{Ce}$ ions, led to the more ideal structural properties (larger special surface area, smaller metal particle size, better metal dispersity) and more reactive oxygen species. Under an oxygen environment, these characteristics may promote the metal-support interaction to form more surface active species such as peroxides $\left(\mathrm{O}_{2}{ }^{-}\right)$ and/or superoxides $\left(\mathrm{O}_{2}{ }^{2-}\right)$ [39]. These results indicated that the $\mathrm{Ti}_{0.9} \mathrm{Zr}_{0.1} \mathrm{O}_{2}$ solid solution was a better alternative as a support than $\mathrm{TiO}_{2}$ in the CWAO of aniline. The catalytic activity on aniline was in the following order: $\mathrm{Ru} / \mathrm{Ti}_{0.9} \mathrm{Zr}_{0.1} \mathrm{O}_{2}>\mathrm{Ru} / \mathrm{Ti} 0.9 \mathrm{Ce}_{0.1} \mathrm{O}_{2}$ $>\mathrm{Ru} / \mathrm{TiO}_{2}$. 

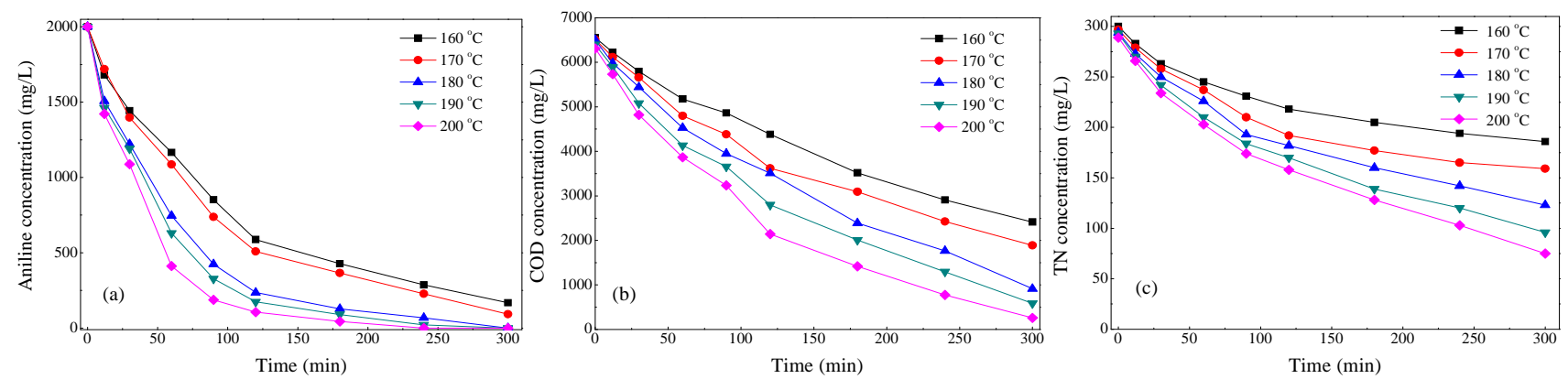

Fig. 7. The effect of reaction temperature on aniline degradation. (a) Aniline concentration; (b) COD concentration; (c) TN concentration.

\subsection{Effect of reaction temperature on aniline degradation}

The reaction temperature was an important operation parameter, which remarkably affected the catalyst oxidation of organic matter. Hence, a series of experiments were performed at approximately $160,170,180,190$ and $200{ }^{\circ} \mathrm{C}$ at $1.5 \mathrm{MPa}$ oxygen pressure. The obtained results over 2 wt $\%$ $\mathrm{Ru} / \mathrm{Ti}_{0.9} \mathrm{Zr}_{0.1} \mathrm{O}_{2}$ are shown in Fig 7. In this case, the activation energy was deduced from the Arrhenius plot and the result was approximately $30.46 \mathrm{~kJ} / \mathrm{mol}$. This value was comparable with the case of $0.5 \mathrm{wt} \% \mathrm{Ru} / \mathrm{Ce}_{0.9} \mathrm{Zr}_{0.1} \mathrm{O}_{2} 108 \mathrm{~kJ} / \mathrm{mol}$ and $\mathrm{Pt}-\mathrm{Ru} / \mathrm{C} 34$ $\mathrm{kJ} / \mathrm{mol}[40,41]$.

Interestingly, the initial reaction rate improved from 2.69 to $4.81 \mathrm{mmol}_{\text {ani }} /\left(\mathrm{h} \cdot \mathrm{g}_{\mathrm{cat}}\right)$ as the reaction temperature was increased from 160 to $200^{\circ} \mathrm{C}$. However, in the absence of any catalyst, the initial reaction rate for the WAO of aniline was just $1.03 \mathrm{mmol}_{\mathrm{a}}$ $\mathrm{ni} /\left(\mathrm{h} \cdot \mathrm{g}_{\text {cat }}\right.$ ) at $200{ }^{\circ} \mathrm{C}$. Consequently, the $2 \mathrm{wt} \% \mathrm{Ru} / \mathrm{Ti}_{0.9} \mathrm{Zr}_{0.1} \mathrm{O}_{2}$ catalyst could efficiently decrease the reaction activation energy, and accelerate the oxidation of aniline. Fig. 7(b) and (c) shows that the variation scopes of $\triangle \mathrm{COD}$ and $\triangle \mathrm{TN}$ were $63 \%-96 \%$ and $38 \%-75 \%$, respectively, from 160 to $200{ }^{\circ} \mathrm{C}$. These results reflected that the reaction temperature had more of an obvious influence on the COD and TN removal than on the aniline conversion because a higher temperature was necessary to decompose the small molecule organic acids and inorganic ammonia. Additionally, the carbonaceous matters were more likely to deposit on the catalyst surface at low temperature and automatically be oxidized at high temperature [42]. The deposited matter covered the active sites and inhibited the adsorption of organics and/or oxygen on the catalyst surface. Therefore, the proper temperature was essential to not only guarantee the necessary energy to degrade the organic matter, but also to enhance the resistance capacity to carbon deposition. However, a higher temperature increases the cost of equipment and energy. Therefore, the optimal operating temperature was set $180^{\circ} \mathrm{C}$.

\subsection{Effect of reaction pressure on aniline degradation}

To evaluate the influence of the oxygen pressure on the catalytic oxidation of aniline, $\mathrm{Ru} / \mathrm{Ti}_{0.9} \mathrm{Zr}_{0.1} \mathrm{O}_{2}$ was tested at $180{ }^{\circ} \mathrm{C}$, under an oxygen pressure of 0.5, 1.0, 1.5 and 2.0 MPa. As shown in Fig. 8(a), the complete aniline conversion was achieved even at a low oxygen pressure. However, the increase of the oxygen pressure obviously improved the COD removal as well as TN conversion, because increasing the oxygen pressure provided more active oxygen species to refractory matter. Hence, increasing the oxygen pressure could accelerate the transmission and activation process (from the gas to the liquid phase, from the liquid phase up to the catalyst surface, and from adsorbed oxygen to the active substance) [43]. Based on the above discussed results, the oxygen pressure was set to $1.5 \mathrm{MPa}$.

\subsection{Distribution of organic matter in CWAO}

The identification of the by-products and intermediates formed upon reaction was essential to identify by-products so as to evaluate their toxicity and design more suitable sewage treatment processes. The residual COD and TN value could not provide sufficient information to assess the degree of degradation. Normally, the oxidation of aniline is not a direct process to form environmentally-friendly substances (organic matter), as it involves a complex process. During the oxidation process, the collected samples underwent a gradual change from an intense reddish-brown color to colorless. This suggested that the
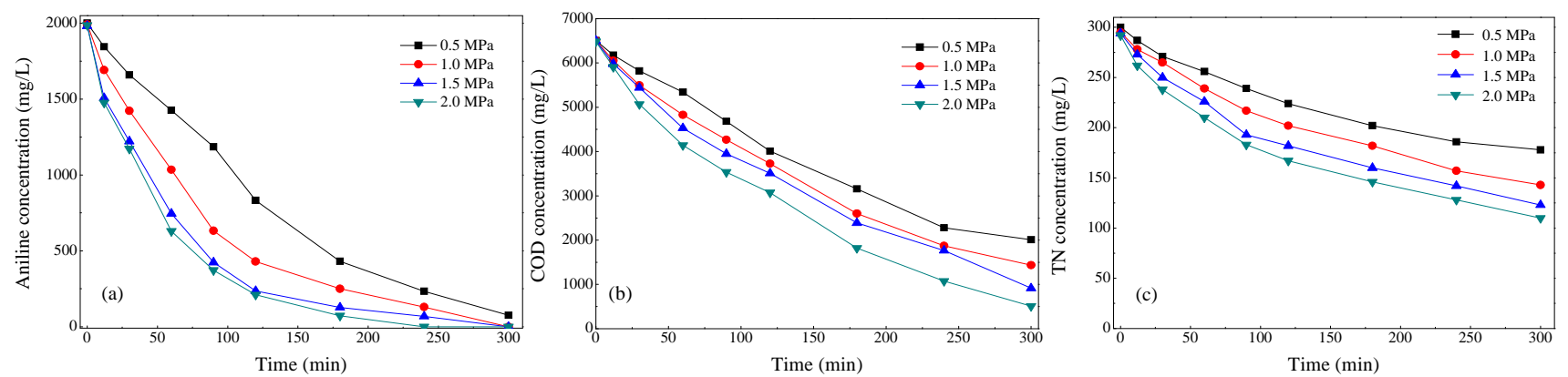

Fig. 8. The effect of reaction pressure on aniline degradation. (a) Aniline concentration; (b) COD concentration; (c) TN concentration. 
CWAO of aniline consisted of two-step paths, where the first step was to form nitrogen-containing organic matter, then further oxidization of the organic matter to colorless organic species occurred. Fig. 9 showed the concentration profiles versus reaction time for aniline and the main intermediate compounds (produced in the oxidation reaction) at $180^{\circ} \mathrm{C}$ and a $1.5 \mathrm{MPa}$ of oxygen pressure over $\mathrm{Ru} / \mathrm{Ti}_{0.9} \mathrm{Zr}_{0.1} \mathrm{O}_{2}$ catalyst.

In the CWAO of phenolic compounds, a free radical mechanism has already been determined [44-46]. During the catalytic oxidation of aniline, the active species $\left(\mathrm{OH}^{*}\right)$ quickly attacks $-\mathrm{NH}_{2}$ groups of aniline to form phenylhydroxyl. This intermediate is not detected owing to its quick disappearance in an aerobic environment [47]. The temporal existence of phenylhydroxyl arises from its transformation into $p$-aminophenol by isomerization or unceasing attack by reactive radicals to produce nitrosobenzene and nitrobenzene. The formed $p$-aminophenol is further oxidized to $p$-nitrophenol by the reactive oxygen species because amino group, as an electron-donating agent, increases the possibility of electrophilic attack [48]. Subsequently, the $\mathrm{N}-\mathrm{C}$ bond on $p$-nitrophenol is broken by a denitration reaction and results in the formation of phenol within $2 \mathrm{~h}$ of reaction. Where after, hydroquinone and benzoquinone is successively derived. Finally, an amount of organic acid (such as acetic acid, succinic acid) is formed as a result of the opening of the aromatic ring. At high temperature, the produced acids accelerated the corrosion of the equipment and led to the dissolution of the active component of the catalyst. Therefore, a rapid removal of the above organic acids is critical to reduce the equipment burden and maintain the catalyst stability. According to the above analysis results and the reported results in the literature, the reaction pathway for the CWAO of aniline is proposed in Fig. 10.

\subsection{Nitrogen distribution analysis}

Treatment of nitrogen-containing compounds through CWAO is a complicated process, where some inorganic compounds (such as ammonium, nitrites and nitrates ions) are generated. Fig. 11 shows the concentrations of the TN, $\mathrm{N}$-organic and inorganic nitrogenous compounds as a function of time over $\mathrm{Ru} / \mathrm{Ti}_{0.9} \mathrm{Zr}_{0.1} \mathrm{O}_{2}$. Experimental results showed that a

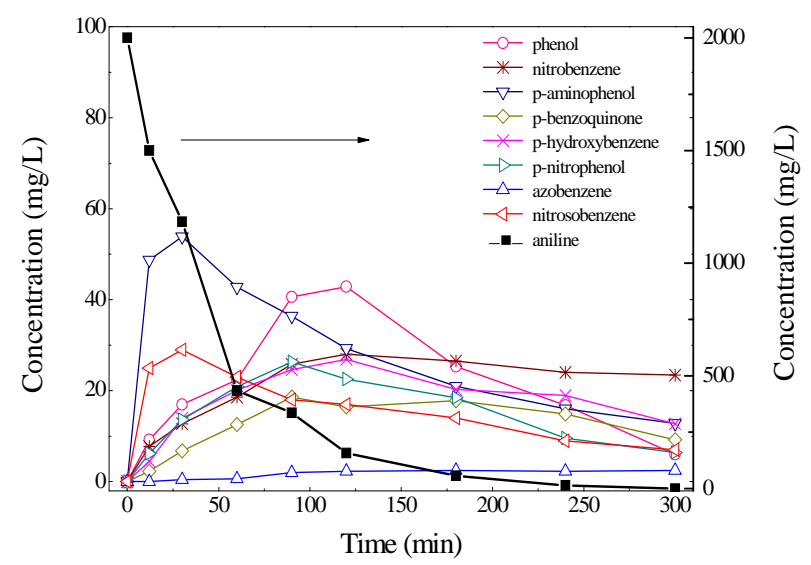

Fig. 9. Concentration profiles of reactant and products in solution with reaction time upon CWAO of aniline.

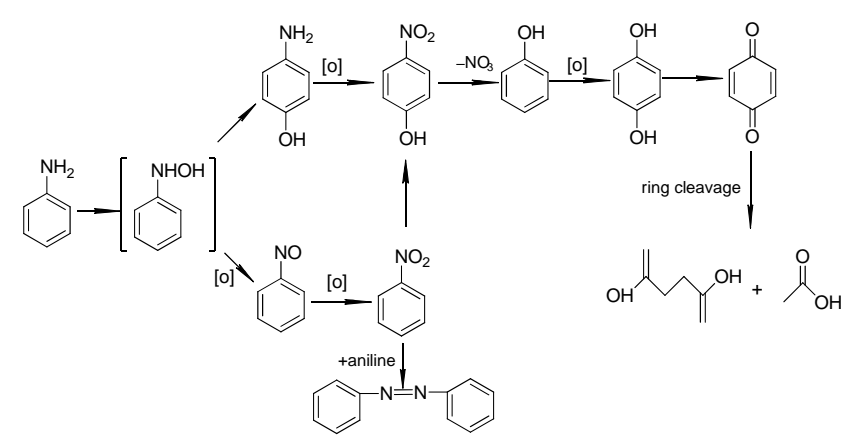

Fig. 10. The reaction pathway for the catalyst oxidation of aniline.

large amount of ammonium ions was quickly produced at the beginning of the reaction and the nitrogen concentration of $\mathrm{NH}_{4}{ }^{+}$achieved a maximum value $(104 \mathrm{mg} / \mathrm{L})$ in the reaction after $2 \mathrm{~h}$. Afterwards, the ammonium ions were transformed into nitrogen and nitrate. Conversely, a conversion of $\mathrm{N}$-organic matter was found, the concentration of which was $23.2 \mathrm{mg} / \mathrm{L}$ after $5 \mathrm{~h}$ of reaction. Hence, the concentration of nitrate ions increased gradually under the experimental conditions. A similar catalytic behavior has been reported by Oliviero et al. [49] where the $\mathrm{N}$-species were mainly transformed into ammonium and nitrate ions using $\mathrm{Ru} / \mathrm{CeO}_{2}$ catalyst under the same operating conditions. However, a small amount of nitrite ions was observed owing to them being unstable during the CWAO process.

\subsection{Stability test}

In the above mentioned catalysts, the $\mathrm{Ru} / \mathrm{Ti}_{0} .9 \mathrm{Zr}_{0.1} \mathrm{O}_{2}$ sample showed the best catalytic stability in the CWAO of aniline after three cyclic experiments. The reduction of COD and TN with the regenerated catalyst was slightly lower than that achieved with fresh catalyst (Fig. 12). A complete conversion of aniline was still achieved after the 3rd run.

After CWAO of aniline at $180{ }^{\circ} \mathrm{C}$ and $1.5 \mathrm{MPa}$ oxygen pressure, the used $\mathrm{Ru} / \mathrm{Ti}_{0.9} \mathrm{Zr}_{0.1} \mathrm{O}_{2}$ was recovered and oven-dried at $120^{\circ} \mathrm{C}$ overnight for analysis. The BET surface area of the spent catalyst decreased slightly to $85.3 \mathrm{~m}^{2} / \mathrm{g}$, which was comparable to that of the fresh catalyst $\left(94.1 \mathrm{~m}^{2} / \mathrm{g}\right)$. The decrease of the

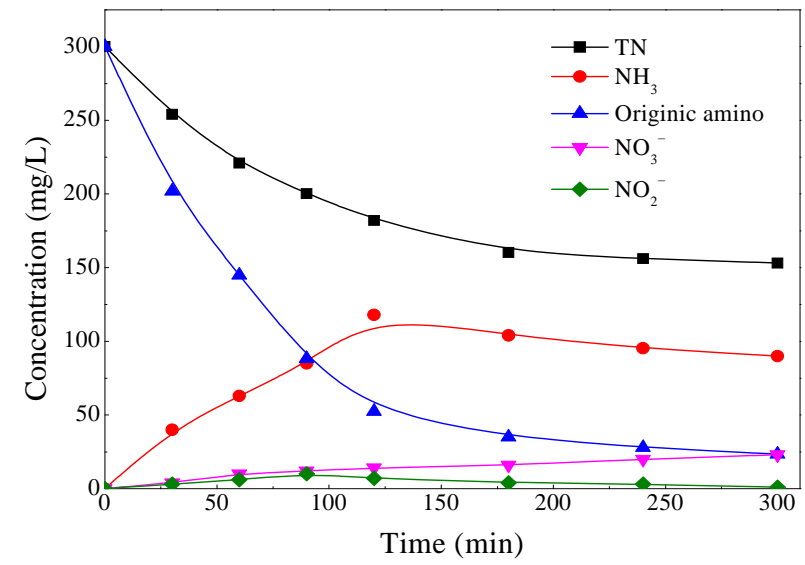

Fig. 11. N-concentration of aniline and by-products in solution with reaction time upon CWAO of aniline. 


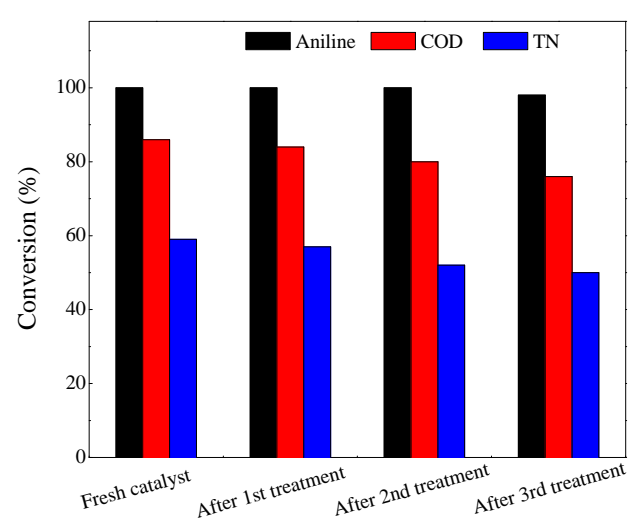

Fig. 12. The cycle experiments of CWAO of aniline using the $\mathrm{Ru} / \mathrm{Ti}_{0.9} \mathrm{Zr}_{0.1} \mathrm{O}_{2}$ catalyst.

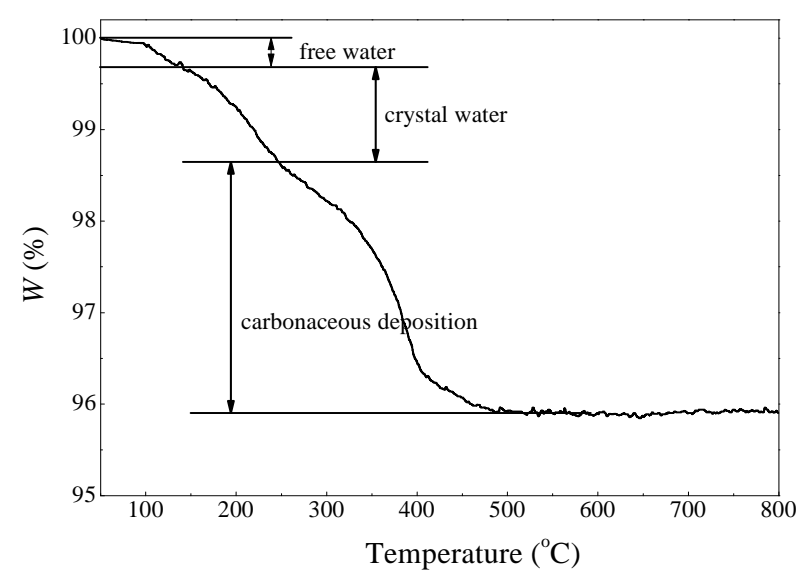

Fig. 13. TG curve of the used catalyst under a nitrogen atmosphere.

specific surface area might be caused by mechanical attrition or the carbon deposition on the catalyst surface. In XRD characterization, the spent catalyst still maintained an anatase crystal structure. Meanwhile, no obvious metal leaching in the ultimate solution revealed a stable activity in CWAO. In the XPS analysis, the content of the surface oxygen species on the spent catalyst was maintained at a high value. Although the formation of some carbonaceous deposits on the surface of the catalyst were evidenced (Fig. 13), these carbonaceous compounds could be removed by calcination and hydrogen treatment. Therefore, the characteristics of high activity, stability and regeneration property makes the $\mathrm{Ru} / \mathrm{Ti}_{0.9} \mathrm{Zr}_{0.1} \mathrm{O}_{2}$ sample a promising candidate for industrial sewage treatment.

\section{Conclusions}

$\mathrm{Ru}$ catalysts supported on Ce- and/or $\mathrm{Zr}$-modified $\mathrm{TiO}_{2}$ were synthesized and their catalytic behavior for the oxidation of aniline was studied. Doping zirconium into titanium could enhance the specific surface area and better disperse the metal. In addition, more of the surface oxygen species and a strong interaction between $\mathrm{Ru}$ and the support were confirmed in the $\mathrm{Ru} / \mathrm{Ti}_{0.9} \mathrm{Zr}_{0.1} \mathrm{O}_{2}$ catalyst.

The $\mathrm{Ru} / \mathrm{Ti}_{0.9} \mathrm{Zr}_{0.1} \mathrm{O}_{2}$ catalyst demonstrated better perfor- mance in the CWAO of aniline, where complete aniline conversion and $88.3 \%$ COD conversion were obtained at $180{ }^{\circ} \mathrm{C}$ and a 1.5 MPa oxygen pressure. Based on the observed intermediate products in solution and the previous reported results, the reaction path for the catalytic oxidation of aniline was established.

A decline of the catalytic activity in the reaction process resulted from the deposition of carbonates on the surface of the catalysts. However, the aged catalysts could recover their activities after calcination and hydrogen treatment and maintain a high oxidation activity even after three consecutive tests.

\section{References}

[1] D. Posada, P. Betancourt, F. Liendo, J. L. Brito, Catal. Lett., 2006, $106,81-88$.

[2] M. E. Suarez-Ojeda, A. Fabregat, F. Stuber, A. Fortuny, J. Carrera, J. Font, Chem. Eng. J., 2007, 132, 105-115.

[3] S. Morales-Torres, A. M. T. Silva, F. J. Maldonado-Hódar, B. F. Machado, A. F. Pérez-Cadenas, J. L. Faria, J. L. Figueiredo, F. Carrasco-Marín, Appl. Catal. B, 2011, 105, 86-94.

[4] G. Ersǒz, S. Atalay, J. Environ. Manage., 2012, 113, 244-250.

[5] M. Fujita, J. M. Lévêque, N. Komatsu, T. Kimura, Ultrason. Sonochem., 2015, 27, 247-251.

[6] F. Tisa, A. A. Abdul Raman, W. D. Wan Daud, J. Environ. Manage., 2014, 146, 260-275.

[7] R. P. Rocha, J. Restivo, J. P. S. Sousa, J. J. M. Órfão, M. F. R. Pereira, J. L. Figueiredo, Catal. Today, 2015, 241, 73-79.

[8] V. S. Mishra, V. V. Mahajani, J. B. Joshi, Ind. Eng. Chem. Res., 1995, $34,2-48$.

[9] S. Shrestha, M. P. Harold, K. Kamasamudram, A. Kumar, L. Olsson, K. Leistner, Catal. Today, 2016, 267, 130-144.

[10] O. P. Taran, A. B. Ayusheev, O. L. Ogorodnikova, I. P. Prosvirin, L. A. Isupova, V. N. Parmon, Appl. Catal. B, 2016, 180, 86-93.

[11] J. Garcia, H. T. Gomes, P. Serp, P. Kalck, J. L. Figueiredo, J. L. Faria, Catal. Today, 2006, 102, 101-109.

[12] P. Oulego, S. Collado, A. Laca, M. Díaz, Chem. Eng. J, 2017, 316, 813-822.

[13] D. M. Fu, F. F. Zhang, L. Z. Wang, F. Yang, Xinmiao Liang, Chin. J. Catal., 2015, 36, 952-956.

[14] H. Z. Ma, Q. F. Zhou, B. Wang, Environ. Sci. Technol., 2007, 41, 7491-7496.

[15] S. X. Yang, X. Li, W. P. Zhu, J. B. Wang, C. Descorme, Carbon, 2008, $46,445-452$.

[16] F. Schmit, L. Bois, F. Chassagneux, C. Descorme, Catal. Today, 2015, 258, 570-575.

[17] J. B. Jr, L. Oliviero, B. Renard, D. Duprez, Top. Catal., 2005, 33, 77-86.

[18] E. Castillejos-López, A. Maroto-Valiente, D. M. Nevskaia, V. Munōz, I. Rodríguez-Ramos, A. Guerrero-Ruiz, Catal. Today, 2009, 143, 355-363.

[19] N. Grosjean, C. Descorme, M. Besson, Appl. Catal. B, 2010, 97, 276-283.

[20] J. L. Fu, K. X. Yang, C. J. Ma, N. W. Zhang, H. J. Gai, J. B. Zheng, B. H. Chen, Appl. Catal. B, 2016, 184, 216-222.

[21] M. A. L. Rocha, G. Del Ángel, G. Torres-Torres, A. Cervantes, A. Vazguez, A. Arrieta, J. N. Beltramini, Catal. Today, 2015, 250, 145-154.

[22] X. Yang, W. B. Wang, L. P. Wu, X. J. Li, T. J. Wang, S. J. Liao, Appl. Catal. A, 2016, 526, 45-52.

[23] G. Borah, P. Sharma, Indian J. Chem. A, 2011, 50A, 41-45. 


\title{
Graphical Abstract
}

Chin. J. Catal., 2017, 38: 1155-1165 doi: 10.1016/S1872-2067(17)62848-1

\section{Catalytic wet oxidation of aniline over $\mathrm{Ru}$ catalysts supported on a modified $\mathrm{TiO}_{2}$}

Mingguang Song, Yunsong Wang *, Yun Guo *, Li Wang, Wangcheng Zhan, Yanglong Guo, Guanzhong Lu East China University of Science and Technology

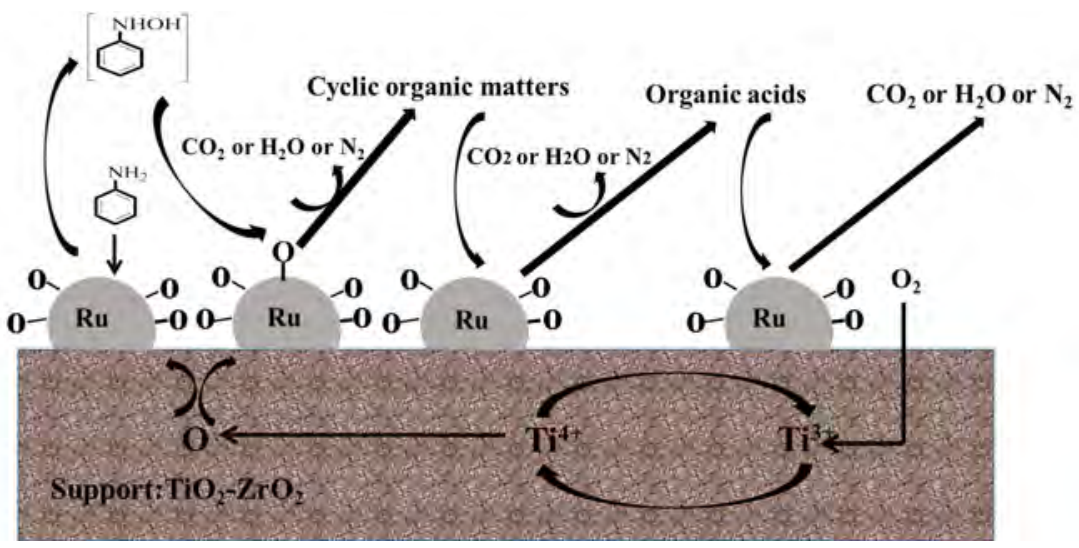

Ruthenium supported on the surface of $\mathrm{Ti}_{0.9} \mathrm{Zr}_{0.1} \mathrm{O}_{2}$ shows high catalytic activity and high stability for catalytic wet oxidation of aniline resulting from homogenous metal dispersion and a higher surface active oxygen content.

[24] J. H. Xu, X. Su, H. M. Duan, B. L. Hou, Q. Q. Lin, X. Y. Liu, X. L. Pan, G. X. Pei, H. R. Geng, Y. Q. Huang, T. Zhang, J. Catal., 2016, 333, 227-237.

[25] K. X. Li, Z. X. Zeng, L. S. Yan, S. L. Luo, X. B. Luo, M. X. Huo, Y. H. Guo, Appl. Catal. B, 2015, 165, 428-437.

[26] M. W. McQuire, C. H. Rochester, J. Catal., 1995, 157, 396-402.

[27] T. N. Pham, D. Shi, T. Sooknoi, D. E. Resasco, J. Catal., 2012, 295, 169-178.

[28] X. H. Lin, K. Yang, R. R. Si, X. Chen, W. X. Dai, X. Z. Fu, Appl. Catal. B, 2014, 147, 585-591.

[29] S. Tada, R. Kikuchi, A. Takagaki, T. Sugawara, S. T. Oyama, S. Satokawa, Catal. Today, 2014, 232, 16-21.

[30] Z. A. Huang, Q. Sun, K. L. Lv, Z. H. Zhang, M. Li, B. Li, Appl. Catal. B, 2015, 164, 420-427.

[31] J. X. Lin, L. M. Zhang, Z. Q. Wang, J. Ni, R. Wang, K. M. Wei, J. Mol. Catal. A, 2013, 366, 375-379.

[32] N. Li, Q. Y. Chen, L. F. Luo, W. X. Huang, M. F. Luo, G. S. Hu, J. Q. Lu, Appl. Catal. B, 2013, 142, 523-532.

[33] Z. M. Liu, Y. N. Lu, L. Yuan, L. L. Ma, L. R. Zheng, J. Zhang, T. D. Hu, Appl. Catal. B, 2016, 188, 189-197.

[34] F. Arena, C. Italiano, G. D. Ferrante, G. Trunfio, L. Spadaro, Appl. Catal. B, 2014, 144, 292-299.

[35] D. M. Fu, F. F. Zhang, L. Z. Wang, F. Yang, X. M. Liang, Chin. J. Catal., 2015, 36, 952-956

[36] F. Arena, R. Di Chio, B. Gumin, L. Spadaro, G. Trunfio, Inorg. Chim.
Acta, 2015, 431, 101-109.

[37] N. Perkas, D. P. Minh, P. Gallezot, A. Gedanken, M. Besson, Appl. Catal. B, 2005, 59,121-130.

[38] J. Barbier, L. Oliviero, B. Renard, D. Duprez, Catal. Today, 2002, 75, 29-34.

[39] N. Li, C. Descorme, M. Besson, Catal. Commun., 2007, 8, 1815-1819.

[40] J. E. Atwater, J. R. Akse, J. A. Mckinnis, J. O. Thompson, Chemosphere, 1997, 34, 203-212.

[41] S. X. Yang, M. Besson, C. Descorme, Appl. Catal. B, 2015, 165, 1-9.

[42] J. Mikulová, S. Rossignol, J. Barbier Jr, D. Duprez, C. Kappenstein, Catal. Today, 2007, 124, 185-190.

[43] L. L. Bo, X. Quan, S. Chen, H. M. Zhao, Y. Z. Zhao, Water Res., 2006, 40, 3061-3068.

[44] L. F. Liotta, M. Gruttadauria, G. D. Carlo, G. Perrini, V. Librando, J. Hazard. Mater., 2009, 162, 588-606.

[45] H. T. Gomes, B. F. Machado, A. Ribeiro, I. Moreira, M. Rosario, A. M. T. Silva, J. L. Figueiredo, J. L. Faria, J. Hazard. Mater., 2008, 159, 420-426.

[46] M. Martín-Hernández, J. Carrera, M. E. Suárez-Ojeda, M. Besson, C. Descorme, Appl. Catal. B, 2012, 123, 141-150.

[47] L. Oliviero, H.Wahyu, J. Barbier, D. Duprez, J. W. Ponton, I. S. Metcalfe, D. Mantzavinos, Chem. Eng. Res. Des., 2003, 81, 384-392.

[48] L. Zhao, J. Maa, Z. Z. Sun, Appl. Catal. B, 2008, 79, 244-253.

[49] L. Oliviero, J. Barbier, D. Duprez, Appl. Catal. B, 2003, 40, 163-184.

\section{改性二氧化钛负载贵金属Ru催化剂催化降解苯胺溶液}

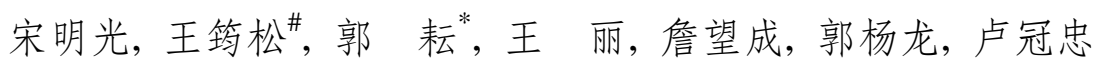 \\ 华东理工大学化学与分子工程学院, 工业催化教育部重点实验室, 上海200237
}

摘要: 苯胺类废水污染物具有结构复杂、浓度高、不易生物降解、生物毒性大等特点, 传统的苯胺降解措施存在着许多弊 端, 很难达到排放标准. 催化湿法氧化技术(CWAO)主要针对降解高浓度难降解的有机废水, 表现出降解效率高、反应时间 短、对生物毒性物质的废水降解效果良好等优点, 越来越受到人们的重视. 但催化剂在使用过程中, 需要在高温高压下进 
行, 且有机物降解产生了有机酸, 使得催化剂的活性组分流失和载体的物理化学性质发生变化, 导致其催化活性下降. 因 此, 需要开发出一种降解活性高, 性能稳定的催化剂成为此技术在工业中广泛应用的关键.

本文采用溶胶凝胶法对二氧化钣进行改性, 制备了 $\mathrm{Ti}_{0.9} \mathrm{Zr}_{0.1} \mathrm{O}_{2}$ 和 $\mathrm{Ti}_{0.9} \mathrm{Ce}_{0.1} \mathrm{O}_{2}$ 载体, 采用过量浸渍法将三氯化钉负载到载 体表面制备了 $2 \% \mathrm{Ru} / \mathrm{Ti}_{0.9} \mathrm{Zr}_{0.1} \mathrm{O}_{2}$ 和 $2 \% \mathrm{Ru} / \mathrm{Ti}_{0.9} \mathrm{Ce}_{0.1} \mathrm{O}_{2}$ 催化剂. 在高温高压反应条件下, 以苯胺为催化湿法氧化污染物, 对不 同催化剂湿法降解苯胺进行比较研究, 系统地探究了催化降解的反应温度和反应压力对苯胺降解的影响. 此外, 利用 HPLC-MS鉴定出催化降解产生的中间产物, 确定了催化降解的反应路径图. 在改性的催化剂中, $2 \% \mathrm{Ru} / \mathrm{Ti}_{0.9} \mathrm{Zr}_{0.1} \mathrm{O}_{2}$ 催化剂 表现出最高的催化降解活性和稳定性. 在初始苯胺浓度 $4 \mathrm{~g} / \mathrm{L}$, 催化剂浓度 $4 \mathrm{~g} / \mathrm{L}$, 反应温度 $180{ }^{\circ} \mathrm{C}, \mathrm{O}_{2}$ 压力 $1.5 \mathrm{MPa}$ 下, 反应 时间 $5 \mathrm{~h}$ 后, 苯胺完全转化, COD转化率达 $88.3 \%$. 并且催化剂进行三次循环试验后, 苯胺转化率仍接近 $100 \%$.

$\mathrm{X}$ 射线衍射和 $\mathrm{N}_{2}$ 物理吸附结果表明, $\mathrm{Ce}, \mathrm{Zr}$ 掺杂到 $\mathrm{TiO}_{2}$ 晶格中形成了共溶体, 其晶格尺寸更小, 比表面积和孔体积更大. 负载贵金属后, 并未出现其他晶相, 说明贵金属均匀分散在载体表面. 透射电镜结果表明, 贵金属负载在改性 $\mathrm{TiO}_{2}$ 上表现出 较好的分散性和较小的颗粒尺寸, 为催化降解苯胺提供更多的催化活性位点, 而 $\mathrm{Ru} / \mathrm{TiO}_{2}$ 催化剂表面, 贵金属发生团聚现象 且颗粒尺寸大. $\mathrm{X}$ 射线光电子能谱结果表明, $\mathrm{Ce}, \mathrm{Zr}$ 的掺杂使得 $\mathrm{TiO}_{2}$ 表面活性氧和四价 $\mathrm{Ru}$ 的含量增加, 更多的表面活性氧成 为催化降解苯胺的直接原因. $\mathrm{H}_{2}$ 程序升温还原结果表明, 在 300-400 ${ }^{\circ} \mathrm{C}$ 处还原峰对应于催化剂载体晶格氧的还原, 改性后, 其还原峰增至2倍, 即使在贫氧环境下, 改性催化剂可以及时从载体中释放晶格氧, 为催化降解苯胺提供更多的活性氧.

关键词: 催化湿法氧化; 物理化学; 苯胺转化率; 碳沉积

收稿日期: 2017-03-15. 接受日期: 2017-05-02. 出版日期: 2017-07-05.

*通讯联系人. 电话/传真: (021)64252943; 电子信箱: yunguo@ecust.edu.cn

\#通讯联系人. 电话/传真: (021)64253703; 电子信箱: yswang@ecust.edu.cn

基金来源: 国家自然科学基金(21333003, 21577034); 国家重点基础研究发展计划(2013CB933200); 国家高技术研究发展计划 (2015AA034603); 中央高校基础科研专项资金(WJ1514020).

本文的英文电子版由Elsevier出版社在ScienceDirect上出版(http://www.sciencedirect.com/science/journal/18722067). 